\title{
MATERIJALNOPRAVNE I PROCESNOPRAVNE KOMPONENTE DEFINISANJA PRAVA POTROŠAČA U BOSNI I HERCEGOVINI
}

\begin{abstract}
Apstrakt: U članku se izlaže stanje i perspektive razvoja zaštite potrošača u Bosni i Hercegovini. Uprkos početnom fragmentarnom preuzimanju pojedinih potrošačkih direktiva EU, ovaj proces je usporen. Usvojen je kodifikovan zakon o zaštiti potrošačkih prava i omogućena sudska zaštita putem kolektivne tužbe. Treba očekivati dalje pokretanje procesa preuzimanja i primjene direktiva EU o zaštiti potrošača u BiH.
\end{abstract}

Ključne riječi: potrošač, trgovac, kodifikacija, zaštita, direktive.

\section{UVOD}

Šta nas je navelo da pristupimo izradi ovog teksta? Kao preliminarna hipoteza, polazimo od pretpostavke da se prava potrošača i njihova zaštita mogu okvalifikovati kao novija pojava u pravnom sistemu/sistemima u Bosni i Hercegovini, ali i šire. ${ }^{1}$ Period reforme pravnog sistema, pod uticajem procesa tranzicije i privatizacije, iznjedrio je pojavu novih, posebnih, zakona koji uređuju niz materijalnopravnih oblasti na način koji odudara od dosadašnje sistematizacije pravnog sistema. Na raznim stranama se javljaju propisi kojima se zaobilaze principi ${ }^{2}$ pojedinih grana prava i značajni izuzeci koji osjetno odstupaju od uobičajenog predmeta i metoda pojedine grane prava. Postepeno se pravni sistem preoblikuje u jedan tranzicijski konglomerat pod uticajem vanjskih faktora, s izgovorom da se približava evropskim i svjetskim nadnacionalnim sistemima, a da se „domaćoj pameti“ ne daje vremena i prostora za kritičko preispitivanje potreba, značaja, domašaja, posljedica ili šteta od brzopletog i bespogovornog slijeđenja volje jačih međunarodnih faktora. Na taj način, tranzicijsko zakonodavstvo postaje jedan šaroliki konglomerat koji domaće zakonodavstvo, pravna

* Pravni fakultet Univerziteta u Banjoj Luci, mail: brankomoraitbm@gmail.com

1 Šolaja, I., Simović, M., 2019, Zaštita prava potrošača u alternativnim mehanizmima za rješavanje potrošačkih sporova, Pravna misao, 5-6, str. 9. Autori navode Rezoluciju Opšte skupštine Ujedinjenih nacija iz 1985, a polovina nabrojanih prava potrošača odraz je ideja predsjednika Kenedija saopštenih u govoru pred Kongresom 5. marta 1962. godine. „Život bez principa je brod bez kormilara.“ Mahatma Gandi 
nauka i sudska praksa teško prepoznaju i slijede, a još teže stavljaju u normalne tokove primjene pravnih normi.

O čemu se ovdje konkretno radi? Kada govorimo o građanskim pravima, podrazumijevamo da ona pripadaju ličnosti koja ima i pravnu i poslovnu, kao i postulacionu sposobnost da ravnopravno sa sebi ravnim ličnostima stupa $u$ raznovrsne građanskopravne odnose $\mathrm{i}$ da bude podvrgnuta istim materijalnopravnim i procesnopravnim propisima koje objedinjuje građansko pravo. Fizičko i pravno lice su pravni pojmovi koji sve ovo objedinjuju kroz čitavu istoriju robnonovčanih odnosa, od starog Rima pa do naših dana. U novije vrijeme, iz ove dve kategorije subjekata prava koji imaju jednak pravni položaj i zaštitu, izdvaja se pojam „potrošač“. Ovaj pojam čini otklon od pravnih pojmova. Njegovo formiranje je vanpravnog značaja i možemo ga podvesti pod ekonomsku kategoriju. Fizička lica, preimenovana i prepoznata kao potrošači, pod dejstvom marketinških kampanja i sopstvenog, prenaglašenog, zgrtalačkog egoizma, postaju plijenom nevjerovatnih manipulacija marketinških faktora na liberalnom tržišnom moru, na pučini koja sirotom potrošaču oduzima moć racionalnog promišljanja i odlučivanja, jer su mu veliki trgovački igrači, tzv. trgovci, preko svojih marketinških stručnjaka usadili „čip“ koji je stvorio „potrošački mentalitet“. Prisustvujemo epohalnoj i globalnoj manipulaciji koja teži i uspijeva da od prosječnog, običnog građanina i sugrađanina stvori nezasitog konzumenta, sakupljača svega i svačega, prividnog blaga koje savremeno tržište, kao more bez granica i s bezbrojnih gusara na njemu, nudi i rasijava u stado koje se bezazleno naziva „potrošačka zajednica“. Izmišljaju se sve noviji i noviji „stari“ proizvodi, ugrađuju se u tehničku robu programirani nepopravljivi kvarovi, organizuju se prodajne akcije u vidu tzv. „crnog petka“ kada se potrošači puštaju u mega tržne centre kao gladijatori u rimske arene. Izmišljeni su razni vidovi zasjeda na koje treba da nasjednu siroti potrošači, razni vidovi agresivne prodaje, razni telefonski pozivi na promocije proizvoda, besplatni ručkovi, nagradne večere ili zamaskirane prodajne akcije, zaskakivanje, na prepad, potrošača na kućnim vratima ili internetski servisi za naručivanje robe koja je virtuelno perfektno prezentirana, ali nije realno ispitana i sl. Sve ovo zajedno čini se kao racionalan motiv za formulisanje prava potrošača i pravne zaštite potrošača. Otuda je, po svemu sudeći, društveno-ekonomski status potrošača kontroverzan i razapet između statusa titulara građanskih prava socijalno ugroženih, prividno zaštićenih, jedinki koje se ne mogu same o sebi starati nego su im potrebni vanjski mehanizmi zaštite koje im uistinu može pružiti samo nacionalna ili nadnacionalna država. Potrošač je, kao „jedna slamka među vihorove" bespoštedne trgovačke utakmice, monopola i njihovih diktata, razvoja i zloupotreba informacionih tehnologija i vještački stvorenog konzumerističkog ambijenta. Polazimo od pretpostavke da nastanak i razvoj potrošačke zaštite, zakonodavstva o zaštiti potrošača i ekspanziju potrošačkog prava dugujemo dobrim namjerama vladajućih faktora u međunarodnom i nacionalnom pravu. 


\section{NASTANAK I RAZVOJ PRAVNE ZAŠTITE POTROŠAČA U BOSNI I HERCEGOVINI}

Vladajuće je mišljenje da pravnu stečevinu (acquis) koju sačinjavaju: osnivački ugovori, zakonodavstvo na bazi osnivačkog ugovora, praksa Suda EU, međunarodni ugovori EU i drugih subjekata i ugovori među državama članicama u oblasti djelatnosti Unije, Bosna i Hercegovina je obavezna preuzimati od potpisivanja Sporazuma o stabilizaciji i pridruživanju između evropskih zajednica i njihovih država članica i Bosne i Hercegovine, tj. od 16. 6. 2008. godine. ${ }^{3}$

Prvi zakon o zaštiti potrošača u Bosni i Hercegovini ${ }^{4}$ donijet je 2002 . godine. ${ }^{5}$ Ovaj zakon sadržavao je opšti dio, zaštitne odredbe, preuzete osnovne potrošačke direktive, upravnopravne odredbe i odredbe o kolektivnoj zaštiti potrošača. Ovaj zakon ne sadrži isključivo građanskopravne odredbe o potrošačkim ugovorima, nego i javnopravne, imperativne norme. $U$ to vrijeme se smatralo, tumačenjem odredbe člana 140. ZZP BiH/02, da su odredbe čl. 48. do 100, kojim su implementirane direktive potrošačkog acquis-a bile privremenog, prelaznog, karaktera dok se ne donese novi zakon kojim je trebalo urediti obligacione odnose. Međutim, to je označilo početak diskusije o metodi regulisanja potrošačkog prava u Bosni i Hercegovini, odnosno implementacije potrošačkog acquis-a, $s$ dva oprečna polazišta: po jednome, treba primijeniti metod kodifikacije i sva potrošačka prava implementirati u jedan zakon, a prema drugom, materiju potrošačkih direktiva treba preseliti u novi zakon o obligacionim odnosima.

Rad na pripremi novog zakona o obligacionim odnosima povjerile su domaće vlade njemačkoj organizaciji GTZ, a ova je za voditelja projekta odredila profesora Helmuta Ruessmana. Vlade entiteta su formirale svoje komisije za izradu novog zakona o obligacionim odnosima. U početku rada je, od strane navedenog profesora, kandidovana ideja da Bosna i Hercegovina treba da dobije potpuno novi zakonik o obligacijama koji bi, za osnovu, imao njemački BGB i holandski novi Građanski zakonik. U toku rada od te ideje se odustalo i za osnovu je uzet jugoslovenski Zakon o obligacionim odnosima iz 1978. godine sa kasnijim izmjenama i dopunama. Što se tiče odredaba o zaštiti potrošača, trebalo je da određena prava potrošača uđu u novi zakon o obligacijama, po uzoru na metod njemačkog Zakona o modernizaciji obligacionog prava, odnosno modernizacije $\mathrm{BGB}-\mathrm{a}^{6}$, a po drugima cjelokupnu materiju direktiva potrošačkog

3 Povlakić, M., 2019, Evropa ante portas - da li su vrata zaključana? (Povodom sudske presude o ugovorima sklopljenim van poslovnih prostorija), Domaća $i$ strana sudska praksa, januarfebruar-mart, str. 11.

4 U daljem tekstu: ZZP BiH/02.

5 Sl. glasnik BiH, br. 17/02, 44/04.

6 Mayer, T., 2002, Reforma obligacionog prava u Nemačkoj, Pravni život, 10, str. 47-59: navodi da je reforma uslovljena sprovođenjem nekih evropskih smjernica, koje su se odnosile na kupovinu potrošnih dobara, zakonsku kamatnu stopu u slučaju kašnjenja sa izvršenjem ugovora i dodatne obaveze davanja informacija kod ugovora zaključenih elektronskim putem (str. 49). Zakon o modernizaciji obligacionog prava stupio je na snagu 1. januara 2002. $\mathrm{Na}$ osnovu evropske smjernice o prodaji potrošnih dobara, potrošačima je za manjkavost 
acquis-a EU trebalo je urediti posebnim zakonima, po uzoru na francusko pravo. ${ }^{7}$ Reforma obligacionog prava u Njemačkoj izvršena je tako što je doneseno nekoliko posebnih zakona, a nakon toga prihvaćene su reformatorske ideje da se ovi zakoni, iz materije zaštite potrošača, ali i drugih nedostajućih obligacionopravnih instituta, integrišu preko Zakona o modernizaciji obligacionog prava u odredbe njemačkog Građanskog zakonika. Prema jednoj struji mišljenja, izvjesnog broja članova udruženih komisija entiteta za izradu nacrta Zakona o obligacijama, direktive EU o različitim pitanjima, često i tehničke prirode, trebalo bi, ako se postigne konsenzus u radu, odmjereno unositi u tekst Nacrta Zakona o obligacijama u $\mathrm{BiH}$, tj. samo neke najopštije odredbe, a sve ostale odredbe, koje nisu opšteg karaktera, trebalo bi ostaviti metodologiji primjene direktiva, kako se ona realizuje za određeni pravni sistem. ${ }^{8}$ Prof. dr Slobodan Perović je iznio svoje mišljenje - da bi sve ostalo trebalo prepustiti posebnim propisima rezervisanim za prava zaštite potrošača, kao što je Zakon za zaštitu potrošača, i trgovačkoj praksi u odnosima između trgovca i potrošača i njihovih asocijacija. ${ }^{9}$ Prof. dr Slobodan Perović je tada isticao da je jugoslovenski Zakon o obligacionim odnosima „kodifikatorski akt i trajni izvor prava za obligacione odnose, koji ne treba da bude podložan čestim izmjenama sitnijih kapilara tržišne privrede, te da su ti, 'sitniji kapilari prometa robe i usluga' upravo predmet regulative smjernica, uputstava i naloga raznih organa i tijela EU, a što je, prema našoj nomotehnici, oblast podzakonske regulative. " ${ }^{10} \mathrm{U}$ zaključku rada komisije za izradu Nacrta $\mathrm{ZOO}$ u BiH zaključilo se da zaštita potrošača ostane sastavni dio Nacrta ZOO. ${ }^{11}$ U skladu s tim, u odredbi člana 15. Nacrta ZOO FBiH-RS/2003 data je definicija preduzetnika, a u odredbi člana 16 . istog nacrta definicija potrošača kao „svakog fizičkog lica koje zaključuje neki pravni posao u svrhu koja ne spada u

robe propisan garantni rok od najmanje dve godine (str. 51). Autor predlaže i da se član 483. ZOO uskladi s novom evropskom regulativom (str. 52). Pored ostalog, u njemački Građanski zakonik uneseno je novo poglavlje sa članovima 474-475 o prodaji potrošnih dobara kako bi se implementirale odredbe smjernice o potrošnim dobrima koje nisu unijete u opšti dio ili u dio o kupoprodajnom ugovoru. Članom 475. GZ-a potraživanje s osnova mana na robi radi se o minimalnim pravima, o imperativnoj normi od koje se ne može odstupiti na štetu potrošača. O postojanju mane, u prvih šest mjeseci, teret dokaza se prenosi u korist potrošača (str. 56). Veliki zahvat je urađen implementacijom posebnih zakona u njemački GZ: Zakona o opštim uslovima poslovanja (čl. 305-310 GZ), Zakona o opozivu ugovora zaključenih sa komercijalnim zastupnicima na kućnom pragu, na različitim mjestima GZ-a, a osnovna norma u članu 312. GZ-a i Zakona o potrošačkim kreditima (čl. 499-505). Posebnim zakonom uređena je tužba udruženja potrošača protiv trgovca koji koristi nepoštene klauzule za opoziv ili nečinjenje (str. 57).

7 Objašnjenja uz prijedlog Nacrta Zakona o obligacionim odnosima, JU Centar za edukaciju sudija i tužilaca u FBiH/ JU Centar za edukaciju sudija i tužilaca u RS u kooperaciji sa GTZ, (Sarajevo/Banja Luka), juli 2006, str. 9.

8 Perović, S., 2002, Stručno mišljenje o Nacrtu Zakona o obligacionim odnosima FBiH/RS sa stanjem 28. 1. 2003, Srpska pravna misao, 1-4, str. 92-94.

9 Objašnjenja uz prijedlog Nacrta Zakona o obligacionim odnosima, str. 9; Perović, S., 2002, str. 93.

10 Morait, B. et al., 2002, Reforma Zakona o obligacionim odnosima u Bosni i Hercegovini (RS i FBiH), Srpska pravna misao, 1-4, str. 22.

11 Objašnjenja uz prijedlog Nacrta Zakona o obligacionim odnosima, str. 10. 
njegovu privrednu ili samostalnu profesionalnu djelatnost“. Te definicije su u Nacrt ZOO/2003. unesene metodom preuzimanja rješenja nekoliko smjernica EU iz oblasti potrošačkog acquis-a. ${ }^{12} \mathrm{U}$ pravnoj periodici ističe se da definicija potrošača nije univerzalna i da se ne pojavljuje kao zajednički nazivnik u smislu potrošačkih kodifikacija. Tako se navodi tzv. transakciona definicija, po kojoj je potrošač fizičko lice koje „u transakcijama obuhvaćenim datom direktivom djeluje u svrhu koja nije u okviru njegove profesije ili zanimanja“. Dalje se napominje da pojedine direktive koriste termin „krajnji ili konačni potrošač“ kao oznaku za kariku u završnoj fazi ekonomskog odnosa. Kao izuzetak navodi se definicija po kojoj pojam potrošač obuhvata širi krug lica „u čije ime je kupovina aranžmana obavljena ili kome je aranžman prenesen, pa tako i osobe u okviru svoje profesije“, kako predviđa Direktiva 90/314/EEC o putničkim aranžmanima. Većina direktiva terminom „potrošač“ označava pojedinca koji stiče dobra i usluge za svoju privatnu, neprofesionalnu upotrebu. ${ }^{13}$ Najopštije definicije daju potrošačke kodifikacije. Tako ZZP BiH/06 potrošača definiše kao „svako fizičko lice koje kupuje, stiče ili koristi proizvode i usluge za potrebe svog domaćinstva“. ${ }^{14}$ Nasuprot, trgovac se definiše, u istom propisu, kao „svako lice koje direktno ili kao posrednik među drugim licima prodaje proizvode ili pruža usluge potrošaču “15, kao i da se proizvođač, koji direktno dostavlja robu ili usluge potrošaču, smatra takođe trgovcem. ${ }^{16}$ Prema Zakonu o zaštiti potrošača RS, „potrošač je fizičko lice koje kupuje, poručuje, stiče ili koristi proizvode ili usluge za svoje potrebe i za potrebe svog domaćinstva ili kome je upućena ponuda za robu ili usluge. ${ }^{17}$ Prema istom propisu, „trgovac je privredno društvo ili preduzetnik koji prodaje robu ili pruža usluge potrošačima u sklopu svoje poslovne djelatnosti ili u druge komercijalne svrhe“. 18

Pored definicije potrošača i trgovca, u Nacrtu ZOO FBiH-RS/2003. bila su uređena i slijedeća pitanja: dostavljanje nenaručenih stvari, elektronske narudžbe, opšti uslovi poslovanja, odgovornost za proizvode i naknada štete zbog nedozvoljenog reklamiranja. U odsjeku o dvostranim ugovorima Nacrta ZOO FBiH-RS/2003. unijete su i odredbe o „pravu opoziva i povrata kod potrošačkih ugovora“. U drugi dio istog nacrta, koji nosi naslov „pojedini ugovori u obligacionim odnosima“, data su pravila za: poslove na kućnim vratima, ugovore o poslovima na daljinu, ugovore o pravu povremenog stanovanja i potrošačke

12 Direktiva 85/577 EWG Vijeća od 20. decembra 1985, koja uređuje zaštitu potrošača u slučaju ugovora zaključenih van poslovnih prostorija; Direktiva 97/7 EZ Evropskog parlamenta i Vijeća od 20. maja 1997. o prodaji na daljinu; Direktiva 93/13 EWG Evropskog parlamenta i Vijeća od 5. aprila 1993. o zabranjenim klauzulama u potrošačkim ugovorima; Direktiva 90/314/EWG Vijeća od 13. juna 1990. o paušalnim putovanjima i Direktiva Evropskog parlamenta i Vijeća od 19. maja 1998. o tužbama na propuštanje radi zaštite interesa potrošača.

13 Bajraktarević, D., 2011, Zaštita potrošača na tržištu finansijskih usluga u Bosni i Hercegovini, Pravna misao, 1-2, str. 10.

14 Član 1. (3) ZZP BiH, Sl. glasnik BiH, br. 25/06.

15 Član 1. (5) ZZP BiH, Sl. glasnik BiH, br. 25/06.

16 Član 1. (6) ZZP BiH, Sl. glasnik BiH, br. 25/06.

17 Član 2. stav 1. tačka a) ZZP RS, Sl. glasnik RS, br. 6/12, 63/14 i 18/17 (u daljem tekstu: ZZP RS).

18 Član 2. stav 1. tačka b) ZZP RS. 
kreditne ugovore. Protivnici unošenja potrošačkog acquis-a u Nacrt ZOO FBiHRS/2003. prigovarali su da se takvom regulativom Zakonu o obligacionim odnosima oduzima trajan karakter budući da su potrošačke smjernice/direktive propisi koji nisu trajnog karaktera i podložni su, po prirodi stvari, čestim izmjenama, te bi se njihovim unošenjem u novi zakon o obligacijama nepotrebno opteretio sadržaj, sistematika i smisao kodifikacije o obligacionim odnosima u $\mathrm{BiH}$. Bilo kako bilo, pod uticajem političkih konfrontacija i stručne kritike teksta Nacrta ZOO/2003, koji je imao čudnu jezičku formu, stranu našem jezičkom izrazu i našem pravničkom vokabularu, Nacrt ZOO FBiH-RS/2003. nije prošao zakonodavnu proceduru. Posljednji pokušaj da se u Bosni i Hercegovini donese novi zakon o obligacionim odnosima izvršila je uža radna grupa ekstrakcijom normi preuzetih iz potrošačkih smjernica/direktiva i formirajući Prijedlog Zakona o obligacionim odnosima 2009. godine, koji, uprkos mnogim redaktorskim zahvatima, takođe nije prošao zakonsku proceduru u Parlamentarnoj skupštini BiH. Pod pretpostavkom da je bio usvojen ZOO FBiH/RS iz 2003. godine, umnogome bi se razlikovao od svih tekstova preuzetog, jugoslovenskog Zakona o obligacionim odnosima iz 1978. Sve bivše jugoslovenske federalne jedinice su, s manjim izmjenama i dopunama, preuzele izvorni tekst $\mathrm{ZOO} / 78$ i ozakonile ga kao sopstveni zakon. Nacrt ZOO FBiH/RS 2003. sadržavao je 1374 člana (563 Opšti dio i 811 Posebni dio) dok je ZOO/78 sadržavao ukupno 1109 članova (453 Opšti dio i 656 Posebni dio). Dakle, Nacrt ZOO FBiH/RS 2003. imao je 265 članova više od ZOO/78 (100 članova više u Opštem dijelu i 155 članova više u Posebnom dijelu). I ovaj podatak ukazuje na teškoće koje bi pratile prepoznavanje ovakvog zakonskog teksta od strane pravničke javnosti.

\section{AKTUELNA REGULATIVA ZAŠTITE POTROŠAČA U BOSNI I HERCEGOVINI}

Sadašnje stanje pravnog uređenja zaštite prava potrošača u Bosni i Hercegovini proizvod je metoda kodifikacije direktiva potrošačkog acquis-a EU u posebnom potrošačkom kodeksu, Zakonu, odnosno zakonima o zaštiti potrošača. Metoda kodifikacije potrošačkih prava je, s obzirom na ishod dijaloga tokom zajedničkog rada komisija za izradu Nacrta ZOO FBiH/RS, prevladala kako u donekle podijeljenoj naučnoj i stručnoj javnosti, tako, nepodijeljeno, u zakonodavnoj praksi. Kako se u stručnoj periodici ističe, metoda kodifikacije ujednačava suprotnosti između pojedinih potrošačkih direktiva i tako povećava koherentnost inače heterogenih propisa koji objedinjuju norme različite pravne prirode. Ipak, postoji i dalje resantiman što se zbog preovlađujuće primjene metoda kodifikacije potrošačkog acquis-a, „[...] pri tome izuzima iz građanske kodifikacije jedno danas veoma značajno pravno područje“. ${ }^{19}$ Ipak, kao pozitivan primjer, koji može poslužiti kao način ispravke pogrešaka domaće kodifikacije prava zaštite potrošača, ističu se rješenja novog Zakona o zaštiti potrošača Republike Hr- 
vatske $^{20}$. Razlog za to je što ovaj propis, u posebno poglavlje, grupiše odredbe o potrošačkim ugovorima i tako ih jasno razlikuje od drugih, pretežno javnopravnih, odredaba ovog zakona, te se predlaže ovakav pristup u budućem noveliranju zakonodavstva u BiH o zaštiti potrošača. ${ }^{21}$ Pored toga, zapaža se i novi zakonodavni trend u materiji propisivanja prava potrošača donošenjem posebnih zakona za svaku pojedinu direktivu potrošakog acquis-a. ${ }^{22}$ Takvom metodom parcijalnog regulisanja, donošenjem posebnih zakona (lex specialis) uređeni su mnogi dijelovi sadržani u potrošačkom acquis-u. ${ }^{23} \mathrm{U}$ pravnoj periodici, autori ističu da je zaštita potrošača nužna „jer je potrošač slabiji učesnik na tržištu u odnosu na profesionalne trgovce, te je zbog toga nužna državna intervencija, kako bi se otklonile ili ublažile negativne posljedice takvog odnosa snaga učesnika tržišne utakmice zbog nezavidnog potrošačkog statusa. ${ }^{24}$

Preteča zaštiti potrošača sadržana je u ZOO/78. Pored osnovnih načela, zaštita subjekata obligacionih odnosa u funkciji potrošača nalazila se u odredbama zaštite principa ekvivalentne razmjene u dvostranim ugovorima, u institutima, kao što su: promijenjene okolnosti (čl. 133-136), prekomjerno oštećenje (čl. 139-140), zelenaški ugovor (član 140), opšti uslovi formularnih ugovora (čl. 142-144), odgovornost proizvođača za štete usljed nedostataka na proizvodu (član 179), odgovornost organizacija koje obavljaju poslove od javnog interesa za štetu nastalu usljed obustavljanja ili neredovnog pružanja usluga (član 184), pravila tumačenja (član 100), odgovornost za materijalne nedostatke (čl. 478-500) i pravila o odgovornosti proizvođača za ispravno funkcionisanje stvari (čl. 501-507).

Zakon o zaštiti potrošača u $\mathrm{BiH}^{25}$ sadrži, po glavama: I - opšte odredbe (lista osnovnih prava potrošača); II - obavezu obavljanja trgovačke djelatnosti na pošten način (pozivanje trgovca na postupanje u skladu sa dobrim poslovnim običajima, prodaju proizvoda i pružanje usluga svim potrošačima pod jednakim uslovima i zabranu diskriminacije, kao i propozicije rasprodaje, plasman proizvoda sa greškom ili istekom roka upotrebe); III - prodaju proizvoda i usluga kao rezultat implementacije Direktive 98/6/ EZ Evropskog parlamenta i Vijeća od 16. 2. 1998. o označavanju cijena, kao i odgovornost trgovca za prodaju proizvoda sa nedostatkom kao rezultat implementacije Direktive 1999/44 Vijeća i Parlamenta o pojedinim aspektima prodaje robe i garancijama. Pošto ove odredbe ZZP-a konkurišu odredbama ZOO o odgovornosti prodavca za materijalne nedostatke,

20 Narodne novine, br. 41/14, 110/15 i 14/19.

21 Povlakić, M., 2019, str. 19.

22 Ibid., str. 18.

23 Takvi su, na primjer: Zakon o nedopuštenom oglašavanju (Sl. glasnik RS, br. 52/12), (Sl. novine $\mathrm{FBiH}$, br. 101/16); Zakon o općoj sigurnosti proizvoda (Sl. glasnik BiH, br. 10/09; Zakon o opštoj sigurnosti proizvoda, Sl. glasnik RS, br. 46/17); Zakon o hrani (Sl. glasnik BiH, br. 40/04), (Sl. glasnik RS, br. 19/17); Zakon o zaštiti žiranata (Sl. novine FBiH, br. 103/13); Zakon o zaštiti korisnika financijskih usluga (Sl. novine FBiH, br. 31/14); Zakon o bankama (Sl. glasnik RS, br. 4/17)

24 Bajraktarević, D., 2011, str. 7.

25 Sl. glasnik BiH, br. 17/02, 44/04 zamijenjen Zakonom o zaštiti potrošača u BiH (Sl. glasnik $\mathrm{BiH}$, br. 25/06 i 88/15) u daljem tekstu: ZZP BiH. 
osnovna razlika se odnosi na dužinu rokova za isticanje nedostatka. Kao što je poznato, prema odredbi člana 482. stav 1 . ZOO nedostatak se mora prijaviti u roku od osam dana po otkrivanju, dok ovaj rok, prema odredbi člana 18. stav 3. ZZP-a, traje dva mjeseca od otkrivanja ili dvije godine od dana predaje robe. Pošto su odredbe ZZP-a u pogledu rokova za zaštitu od nedostatka povoljnije za potrošača, to je njihova primjena u prednosti nad primjenom pravila o rokovima iz ZOO. IV - propisuje uslove za deklarisanje proizvoda; V - sadrži propis o odgovornosti proizvođača za proizvod s greškom i upućuje na primjenu pravila ZOO; VI - sadrži odredbe o garanciji za proizvod ili uslugu i upućuje na primjenu pravila ZOO; VII - o oglašavanju proizvoda i usluga, kao rezultat implementacije Direktive 84/450 EEC od 10.9. 1984. o reklami koja potrošača dovodi u zabludu i Direktive 97/55/EZ Evropskog parlamenta i Vijeća od 6. 10. 1997. koja uređuje uporedno reklamiranje; VIII - uređuje odnose povodom ekonomskih usluga od opšteg interesa; IX - uređuje ugovore zaključene van poslovnih prostorija radi implementacije Direktive 85/577/EEZ od 20. 12. 1985. o ugovorima zaključenim izvan poslovnih prostorija; $\mathrm{X}$ - propisuje uslove prodaje na osnovu ugovora zaključenog na daljinu, kao rezultat implementacije Direktive 97/7/EZ Evropskog parlamenta i Vijeća od 20. 5. 1997. o ugovorima na daljinu; XI - o potrošačkom kreditu, nastala implementacijom Direktive 87/102/EEZ od 22. 12. 1986. o potrošačkim kreditima sa izmjenama i dopunama u Direktivi 90/88/EEZ od 22. 2. 1990 i Direktivi 97/7/EZ Evropskog parlamenta i Vijeća od 16. 2. 1998. godine; XII - osiguranje; XIII - uređuje elektronska sredstva plaćanja, a XIV turističke paket-aranžmane u cilju implementacije Direktive 90/314/EEZ od 13. 6. 1990. o turističkim paket-aranžmanima; XV - sadrži vremenski zakup turističkog objekta, kao rezultat implementacije Direktive 94/47/EC od 26. 10. 1994. o ugovoru o zakupu turističkih objekata; XVI - propisuje nepravedne odredbe u potrošačkim ugovorima, zasnovano implementacijom Direktive 93/13/EEC od 5. 4. 1993. o nepravičnim odredbama u potrošačkim ugovorima; XVII - određuje nosioce zaštite potrošača u BiH; XVIII - upravne mjere zaštite potrošača; XIX - procesnopravnu zaštitu potrošača, a XX - kaznene mjere zaštite potrošača.

Poređenja radi, Zakon o zaštiti potrošača Republike Srpske ${ }^{26}$ sadrži slijedeće odredbe, sistematizovane u posebne glave (I-XIX): Opšte odredbe (čl. 1-7); Zaštita bezbjednosti života i zdravlja potrošača (čl. 8-12); Obaveza obavljanja trgovačke djelatnosti u skladu sa dobrim poslovnim običajima (čl. 13-17); Prodaja proizvoda i pružanje usluga (čl. 18-31); Deklarisanje proizvoda (čl. 32-33); Odgovornost i garancija za proizvod i uslugu (čl. 34-45); Usluge od opšteg ekonomskog interesa (čl. 46-54); Ugovori zaključeni van poslovnih prostorija (čl. 55-589); Prodaja na osnovu ugovora na daljinu (čl. 59-69); Nepoštene odredbe u potrošačkom ugovoru (čl. 70-74); Elektronski instrumenti plaćanja (čl. 75-83); Turistički paket-aranžman (čl. 84-104); Vremensko korišćenje nepokretnosti u turizmu (čl. 105-119); Zaštita potrošača (čl. 120-125), Zaštita prava potrošača (čl. 126-136), Nadzor, Kaznene odredbe (čl. 137-148); Prelazne i završne odredbe (čl. 149-156). 
Zbog donošenja ZZP RS komentatori ocjenjuju da ZZP BiH neće opstati kao mjesto gdje će se implementirati nove direktive EU o zaštiti potrošača. Smatraju da se može očekivati da će se daljnja implementacija direktiva EU iz potrošačkog acquisa-a u Republici Srpskoj vršiti izmjenama i dopunama ZZP RS ili donošenjem posebnih entitetskih zakona, tako da će u Federaciji BiH i Brčko Distriktu $\mathrm{BiH}$ važiti ZZP BiH iz 2006. godine, koji je, uprkos mnogim novim direktivama EU, ostao neažuriran. ${ }^{27}$ Zapaža se i da je Republika Srpska, uporedo s metodom kodifikacije na entitetskom nivou, nastavila i s korištenjem metoda specijalizacije propisa, donošenjem novih posebnih zakona kao što su: Zakon o bankama, u koji je unesena Direktiva o potrošačkom kreditu, Zakon o nedopuštenom oglašavanju i dr. $U$ tom pravcu ide i razvoj potrošačkog zakonodavstva u FBiH - donošenjem Zakona o zaštiti korisnika finansijskih usluga, Zakona o finasijskom poslovanju, Zakona o nedopuštenom oglašavanju i $\mathrm{dr}^{28}$

Problem izbora najadekvatnijeg metoda regulisanja zaštite potrošača i složenosti ove materije može se ilustrovati primjerom disperzije propisa koji sadrže, ponaosob, odredbe propisa o zaštiti potrošača finansijskih usluga u Bosni i Hercegovini. ${ }^{29}$

Pravna stečevina EU na području zaštite prava potrošača formira se donošenjem sekundarnih pravnih akata (smjernica/direktiva). Ovi opšti pravni akti ne djeluju direktno na privatno-pravne subjekte, nego obavezuju države-članice da svoje pravo harmonizuju s odredbama sadržanim u direktivama koje, uglavnom, predstavljaju direktive minimalne harmonizacije, tj. određuju minimalne standarde zaštite potrošača. Takvi pravni akti ostavljaju državama-članicama slobodu propisivanja strožih normi, odnosno većeg stepena zaštite potrošača. ${ }^{30}$ Uprkos postojanju stotinjak potrošačkih direktiva, zapažaju navođeni pravni teoretičari, ne postoji jedinstven pristup pojmu „potrošački ugovor“. U sadašnjoj pravnoj

27 Povlakić, M., 2019, 24.

28 Ibid., str. 24-25.

29 Dva zakona o obligacionim odnosima, u FBiH, Sl. glasnik SFRJ, br. 29/78, 39/85, 45/89, 57/89 i Sl. list RBiH, br. 2/92, 13/93, 13/94, Sl. novine FBiH, br. 29/03 i u Republici Srpskoj: Sl. glasnik SFRJ, br. 29/78, 39/85, 45/89, 57/89 i Sl. glasnik RS, br. 17/93 i 3/96; dva zakona o bankama: Sl. novine FBiH, br. 39/98, 32/01, Sl. glasnik RS, 44/03; Zakon o osiguranju depozita u bankama BiH (Sl. glasnik BiH, br. 20/02, 18/05, 100/08, i 75/09); Zakon o tržištu vrijednosnih papira (Sl. novine FBiH, br. 85/08); Zakon o tržištu hartija od vrijednosti (Sl. glasnik RS, br. 92/06); Zakon o Agenciji za bankarstvo FBiH (Sl. novine FBiH, br. 9/96, 27/98, 20/00, 45/00); Zakon o bankama RS (Sl. glasnik RS, br. 3/16); Zakon o Agenciji za bankarstvo RS (Sl. glasnik $R S$, br. 10/98, 10/00, 18/01, 71/02, 18/03, 39/03); Zakon o Komisiji za vrijednosne papire (Sl. novine $\mathrm{FBiH}$, br. 39/98, 16/00, 18/01, 71/02, 18/03, 39/03); dva zakona o mikrokreditnim organizacijama; Zakon o Agenciji za osiguranje $\mathrm{BiH}$ (Sl. glasnik BiH, br. 12/04); Zakon o društvima za osiguranje u privatnom osiguranju (Sl. novine $\mathrm{FBiH}$, br. 22/05), Zakon o posredovanju u privatnom siguranju ( $\mathrm{Sl}$. novine $\mathrm{FBiH}$, br. 22/05), Zakon o društvima za osiguranje (Sl. glasnik RS, br. 17/05, 01/06, 64/06); Zakon o osiguranju od odgovornosti za motorna vozila i ostalim obaveznim osiguranjima od odgovornosti (Sl. glasnik RS, br. 17/05, 64/06); Zakon o posredovanju u osiguranju (Sl. glasnik RS, br. 17/05, 64/06); Zakon o zaštiti korisnika finansijskih usluga ( $\mathrm{Sl}$. novine $\mathrm{FBiH}$, br. 31/14); Zakon o mikrokreditnim organizacijama RS (Sl. glasnik RS, br. 116/11); Zakon o zaštiti žiranata FBiH (Sl. novine FBiH, br. 100/13).

30 Bikić, E., Petrović, A., 2011, Koncept potrošačkog ugovora u pravu BiH, Pravna misao, 3-4, str. 37. 
sistematizaciji, moguće je govoriti o trojakom segmentiranju privatno-pravnih ugovora na: trgovačke (preduzetničke), potrošačke i opšte obligacionopravne ugovore. ${ }^{31}$ Navode se i kriteriji definisanja „potrošačkog ugovora“, kao što su: status jedne ugovorne strane mora se definisati kao potrošač, učesnik transakcije kao kupac ili korisnik usluge, s druge strane, trgovac je prodavac ili vršilac usluge, a motiv, cilj ili svrha potrošačke transakcije mora biti sticanje dobra ili usluge za ličnu, neprofesionalnu upotrebu. ${ }^{32}$

U prilog argumentaciji koja podržava metod parcijalnog uređivanja prava potrošača, ističe se stav po kojem evropsko pravo zaštite potrošača ne čini zasebnu granu prava, već samo fragmentarnu dopunu prava država članica, te da je ono „heterogen, nekoherentan i fragmentaran skup normi javnopravnog i privatnopravnog karaktera “. ${ }^{33}$ Potrošačko ugovorno pravo sastoji se iz dva dijela, jednog koji reguliše marketing prodaju i drugog koji normira pojedine tipove ugovora. ${ }^{34}$ Kao što je poznato, Rezolucijom Evropskog parlamenta od 26. maja 1989. godine, zaključeno je da je: „[...] unifikaciju moguće izvršiti u granama građanskog prava koje su od velike važnosti za razvoj jedinstvenog tržišta, kao što je ugovorno pravo[...]“. ${ }^{35} \mathrm{Za}$ razliku od kodifikacije privatnopravnih i javnopravnih segmenata u Zakonu o zaštiti potrošača, u Republici Hrvatskoj je u Zakon o obveznim odnosima ${ }^{36}$ ugrađen znatan broj odredaba potrošačkih direktiva, a taj model implementacije zaživio je prilikom modernizacije njemačkog Građanskog zakonika. ${ }^{37}$

Uprkos navedenim promjenama u uporednim pravnim sistemima, domaći autori zaključuju da je pozitivan korak reforme u cilju usklađivanja domaćeg prava sa evropskom pravnom stečevinom svojevremena transformacija Nacrta ZOO FBiH/RS u Prijedlog ZOO BiH, iz kojeg teksta je odstranjen segment potrošačkog acquis-a. Autori takav ishod smatraju pozitivnim „jer čitav niz potrošačkih odnosa još uvijek nije predmet zakonske regulative, a česte intervencije u kodifikaciju obligacionog prava, implicirane čestim izmjenama potrošačkih direktiva, nisu niti poželjne niti moguće“. ${ }^{38}$ Smatramo odmjerenim stanovište da je pojam potrošač dio ekonomskog diskursa i da njegovo prenošenje u pravni kontekst izaziva niz kontroverzi. ${ }^{39}$ Valja ukazati i na to da neminovnu pojavu međusobne neusklađenosti domaćih propisa o zaštiti potrošača može da otkloni odredba člana 1. stav 2. ZZP BiH, prema kojoj: „ [...] u slučaju nedoumica ili sukoba odredbi primjenjivat će se odredba koja pruža veći stepen zaštite potrošača“" 40

$31 \quad$ Ibid., str. 58.

32 Ibid., str. 57.

33 Ibid., str. 38.

34 Ibid.

35 Ibid., str. 40.

36 Narodne novine, br. 35/05 i 41/08.

37 Bikić, E., Petrović, A., 2011, str. 42.

38 Ibid., str. 43.

39 Ibid., str. 52.

$40 \quad$ Ibid., str. 44. 


\section{INSTITUCIONALNI OKVIR PRAVNE ZAŠTITE POTROŠAČA}

U vrijeme donošenja prvog Zakona o zaštiti potrošača $\mathrm{BiH}$ iz 2002. godine, doneta je Odluka Savjeta ministara o pokretanju postupka izrade Strategije integrisanja Bosne i Hercegovine u Evropsku uniju. Ovom strategijom izražena je politika zaštite potrošača koja treba da, između ostalog, obezbjedi potpunu i dosljednu primjenu zakona o zaštiti potrošača; osposobi institucije za zaštitu potrošača; razvije sistem nadgledanja tržišta radi osiguranja zaštite života i zdravlja potrošača; intenzivira saradnju subjekata za zaštitu potrošača; razvija saradnju sa organima zaštite potrošača $u$ drugim zemljama i međunarodnim organizacijama; uspostavi sistem alternativnog rješavanja potrošačkih sporova; provodi edukaciju i informisanje potrošača; razvija i finansira nevladine organizacije iz oblasti zaštite potrošača i podstiče učlanjenje tih udruženja u međunarodne asocijacije zaštite potrošača. ${ }^{41}$ Početkom 2008. formirano je Vijeće za zaštitu potrošača, kao stručno konsultativno tijelo Savjeta ministara $\mathrm{BiH}$, sa zadatkom pripreme godišnjeg programa zaštite potrošača i, nakon usvajanja od Savjeta ministara $\mathrm{BiH}$, praćenja izvršavanja tog programa. Članove Vijeća za zaštitu potrošača, sa određenim brojem predstavnika, imenovali su: Savez udruženja potrošača $\mathrm{BiH}$, organizacije potrošača entiteta, te jedanaest predstavnika vladinog sektora $\mathrm{s} \mathrm{dr}$ žavnog i entitetskog nivoa. ${ }^{42}$

Zakonskim aktima je proklamovano učešće mnogih organa ili tijela državne i lokalne vlasti, raznih asocijacija, komora, udruženja, nevladinih organizacija, ombudsmana raznih profila i sl. Sve se svodi na vansudsko ili sudsko procesuiranje zaštite poštrošača. Ovdje treba zastati. Za pravničko rezonovanje osnovna i najvažnija je sudska zaštita nečijih prava. Pravničko rezonovanje polazi i završava se sa sudskom zaštitom prava. Naravno da se misli na subjektivna građanska prava i njihov izraz tužbe u materijalnom smislu. Ali, kako smo na početku ovog rada iznijeli, prava potrošača se teško mogu okvalifikovati u svakom slučaju kao subjektivna građanska prava. Jer da su prava potrošača subjektivna građanska prava u materijalnopravnom smislu, onda ne bi trebalo formirati zakonski okvir prava potrošača, nego bi sve moglo stati u okvir građanskog prava kao grane prava.

Kako sada stvari stoje, osnovni prigovor potrošača na povredu njegovih prava, adresiran je na trgovca. Trgovac je dužan da vodi knjigu reklamacija, a potrošač može podnijeti reklamaciju u pismenoj formi, uz kopiju fakture, u roku od osam dana od prijema robe ili izvršenja usluge. Trgovac je dužan na prigovor odgovoriti u roku od osam dana te, na zahtjev potrošača i po njegovom izboru: ukloniti nedostatak, zamijeniti neispravni proizvod isovjetnim ispravnim proizvodom, vratiti plaćeni iznos cijene i naknaditi troškove ili umanjiti cijenu. Ako nedostatak nije vidljiv, zahtjev (prigovor) se podnosi u roku od 60 dana od otkrivanja nedostatka, ili najkasnije u roku od dvije godine od dana prijema robe s nedostatkom.

41 Sabljica, S., 2015, Politika zaštite potrošača u Bosni i Hercegovini u procesu evropskih integracija, Pravna misao, 3-4, str. 59.

42 Ibid., str. 65. 
Udruženja za zaštitu potrošača mogu, po pismenoj obavijesti potrošača, provesti postupak posredovanja u rješavanju prigovora potrošača. Niz ministarstava, inspekcijskih organa i Vijeće za zaštitu potrošača BiH imaju stratešku ulogu u zaštiti potrošača.

Vansudsku zaštitu, kao vid alternativnog rješavanja "potrošačkih sporova“, pruža i Arbitažni odbor za potrošačke sporove pri Privrednoj komori Republike Srpske i Arbitražni odbor za potrošačke sporove pri Zanatsko-preduzetničkoj komori Republike Srpske. Postupak pred nadležnim odborom pokreće se tužbom u roku od 30 dana od odbijanja zahtjeva (prigovora) potrošača ili u roku od 30 dana zbog neriješavanja (ćutanja) trgovca povodom prigovora potrošača. Zakon je isključio mogućnost alternativnog rješavanja „potrošačkog spora“ ukoliko je povreda prava potrošača imala za posljedicu smrt, tjelesnu povredu ili oštećenje zdravlja potrošača, kao i za pružanje zdravstvenih usluga i povodom transfera prava na nekretninama, kao i ako vrjednost predmeta spora premaša iznos od 10.000,00 KM.

Ombudsman za zaštitu potrošača formiran je primjenom odgovarajućih odredaba $\mathrm{ZZP} \mathrm{BiH/} \mathrm{2006.} \mathrm{Ombudsman} \mathrm{za} \mathrm{zaštitu} \mathrm{potrošača} \mathrm{BiH} \mathrm{odlučuje} \mathrm{o} \mathrm{žal-}$ bama potrošača. Ombudsman je nadležan da štiti kolektivne interese potrošača i pokreće sudske sporove. Uz razna informativna, istraživačka, savjetodavna, pregovaračka ovlašćenja, najvažnija mu je uloga pokretanje sudskog postupka za naknadu štete nanesene kolektivnim interesima potrošača.

Unatoč institucionalnom okviru sa mnoštvom učesnika u zaštiti potrošača, njihova se uloga ocjenjuje kao deklarativna. Zapaža se da ZZP BiH, kao jedan od potrošačkih kodeksa u $\mathrm{BiH}$, nije uredio međusobni odnos između mnoštva nadležnih organa i institucija za zaštitu potrošača, što je rezultiralo nepovezanim i neusklađenim aktivnostima i nije doprinijelo očekivanom poboljšanju zaštite potrošača. ${ }^{43}$

\section{PRAVO POTROŠAČA NA SUDSKU ZAŠTITU}

Stara je istina da dok se sudskom odlukom ne utvrdi nečije pravo, to pravo i ne postoji, odnosno samo je zapisano na papiru. Stoga, bez preduzimanja radnji u cilju pravne zaštite vansudskim ili sudskim putem, čitava biblioteka zakonskih i ostalih pravnih akata ostaje mrtvo slovo na papiru, kako se to inače kaže.

Izmjene i dopune Zakona o parničnom postupku Republike Srpske iz 2013. godine u posebne parnične postupke implementirale su procesna pravila za tužbu kojom se štite kolektivna prava potrošača. U Zakonu o parničnom postupku Republike Srpske ${ }^{44}$ uređeni su posebni postupci. ${ }^{45}$ U Glavi XXXa ZPP RS ure-

43 Bajraktarević, D., 2011, str. 25.

44 Sl. glasnik Republike Srpske, br. 58/03, 85/03, 74/05, 63/07, 105/08 - odluka US, 45/09 - odluka US i $61 / 13$.

45 Postupak u parnicama iz radnih odnosa (čl. 419-422), postupak u parnicama zbog smetanja posjeda (čl. 423-427), postupak u sporovima male vrijednosti (čl. 428-43), postupak u privrednim sporovima (čl. 433aq-433e), postupak pred arbitražom (čl. 434-453). 
đena je tužba za zaštitu kolektivnih prava i interesa (čl. 453a-453ž). Aktivnu legitimaciju za podnošenje tužbe imaju udruženja, organi, ustanove i druge organizacije koje su registrovane za zaštitu kolektivnih prava potrošača. ${ }^{46}$ Pasivno su legitimisana fizička ili pravna lica koja ugrožavaju kolektivna prava i interese potrošača, ali i interese zaštite čovjekove životne sredine, antidiskriminacije i neetičkih postupanja. Povrede potrošačkih ugovora nepoštenim odredbama na štetu potrošača mogu rezultirati kolektivnom tužbom koja obuhvata veći broj trgovaca koji se služe nepoštenom ugovornom praksom. Beneficirana je mogućnost izbora mjesne nadležnosti u korist potrošača, jer je pored osnovnog suda opšte mjesne nadležnosti nadležan i sud prebivališta/boravišta potrošača. ${ }^{47}$ Tužbeni zahtjev ide za utvrđenjem da su postupanjem ili propuštanjem tuženog povrijeđena prava ili kolektivni interesi potrošača i da se zabrane radnje ili propuštanja kojima se povrijeđuju ili ugrožavaju prava potrošača; da se naredi prestanak štetnih radnji, otklanjanje štete, uspostavljanje pređašnjeg stanja i objavljivanje presude u sredstvima javnog informisanja o trošku tuženog. Na prijedlog tužioca sud može odrediti privremene mjere obezbjeđenja ako tužilac dokaže da je tuženi svojim radnjama ili propuštanjima povrijedio ili ugrozio prava i interese tužioca, koji se u tužbi navode, ili da prijeti nenadoknadiva šteta ili da se mjerama spriječava nasilje nad tužiocem. Sudska mjera obezbjeđenja može sadržavati utvrđenje privremenih pravila za bezbjedno obavljanje djelatnosti tuženog.

U pravnoj periodici u Bosni i Hercegovini nedostaju prikazi slučajeva iz sudske prakse u oblasti zaštite prava potrošača. Jedan o rijetkih primjera iz sudske prakse koji je prikazan jeste spor male vrijednosti povodom zaključenja ugovora van poslovnih prostorija između fizičkog lica (potrošača) i preduzeća iz oblasti telekomunikacija (trgovca) o korištenju usluga mobilne telefonije. ${ }^{48} \mathrm{U}$ prikazanom slučaju, trgovac je s potrošačem kontaktirao ispred jednog tržnog centra, ali ga tom prilikom nije obavijestio o njegovom pravu na raskid ugovora, što je bio dužan učiniti po odredbi čl. 40. i 41. ZZP BiH, a teret dokaza da je to učinio leži na trgovcu. ${ }^{49}$ Potrošač se, u žalbi, pozvao na Direktivu 85/577/EEZ o ugovorima zaključenim van poslovnih prostorija koja nije potpuno implementirana u ZZP BiH /2006 i Direktivu 2011/83/EU koja nije uopšte implementirana, a kojom je rok za odustanak od zaključenog posla, kada trgovac nije obavijestio potrošača o pravu na odustanak, produžen na 12 mjeseci od isteka roka za odustanak. ${ }^{50}$ Sud je odbio žalbu potrošača s obrazlo-

46 Prema navodima portala POLITIKA od 13. 4. 2020. U 10:49, „oko 4.000 turista iz Njemačke, koji su se zarazili korona virusom, priključuju se tužbi Udruženja za zaštitu potrošača (VSV) protiv austrijskog skijaškog centra Išgl. Prema navodima 'Dojče Velea' kolektivnoj tužbi priključilo se 4.000 Nemaca koji su u tom gradiću inficirani. Predsednik VSV Peter Kolba je podneo prijavu tužilaštvu Tirola, koje mora da istraži slučaj i odluči da li postoji osnova za obeštećenje pogođenih. Kolba naglašava da je bilo finansijskih i političkih razloga da se odloži na što kasnije prekid skijaške sezone, preneo je Tanjug.“

47 Član 33a ZPP RS (Sl. glasnik RS, br. 58/03, 85/03, 74/05, 63/07, 105/08 - odluka US, 45/09 i $63 / 13$.

48 Povlakić, M., 2019, str. 11. Profesorica ukazuje da je ovaj potrošački spor čest u praksi i da to dokazuje da je acquis već dio pravnog poretka $\mathrm{BiH}$.

49 Ibid., str. 12.

50 Ibid. 
ženjem da nije otkazao ugovor preporučenom poštom, a što nije ni bio obavezan, jer se po ZZP BiH 2006. zahtijeva samo obavijest u pismenoj formi. ${ }^{51}$ Prof. Povlakić, u komentaru ovog slučaja iz sudske prakse, ističe da je pravo potrošača na odustanak od zaključenog ugovora u kontradikciji s načelom pacta sunt servanda ${ }^{52}$, ali da opšte ugovorno obligaciono pravo podrazumijeva formalnu jednakost stranaka, koja u slučaju kada je jedna ugovorna strana potrošač mora da se potisne zbog svekolike inferiornosti potrošača (ekonomske, tehničke, informacione) u odnosu na trgovca. Stoga evropski zakonodavac daje prednost zaštiti potrošača u odnosu na opšta pravila obligacionog prava. Kada se kao ugovorna strana pojavljuje potrošač, održavanje principa ravnopravnosti strana potrošački acquis EU propisuje imperativnim normama. Tako je pravo na odustanak od ugovora njegovo neotuđivo pravo i njega se potrošač ne može odreći, a potrošačkim zahtjevom ne može slobodno disponirati, što znači otklon od dispozitivnosti normi obligacionog prava i načela autonomije volje ugovarača, te da je to suština potrošačkog prava koje se, u tim segmentima, razlikuje od opšteg ugovornog prava. ${ }^{53} \mathrm{Na}$ pitanje da li neimplementirana direktiva može neposredno djelovati, prof. Povlakić odgovara potvrdno, te da je sud, u konkretnom slučaju, bio dužan da nacionalno pravo tumači u skladu s neimplementiranom direktivom. ${ }^{54} \mathrm{U}$ ovom primjeru iz sudske prakse vidi se da sud nije u stanju prebroditi teškoće u primjeni potrošačkog acquis-a EU da tumači nacionalno pravo u skladu s neimplementiranom direktivom EU. Po principu iura novit curia - sud je obavezan da poznaje pravo. Međutim, direktive se ne objavljuju u domaćim službenim glasilima, što objašnjava ali i ne opravdava indolenciju sudova da ne primjenjuju i ne tumače direktive potrošačkog acquis-a EU. Najzad, da bi država koja ima zaključen Sporazum o stabilizaciji i pridruživanju bila ocijenjena kao sposobna za članstvo u EU, nije dovoljan, pa čak ni presudan, nivo usklađenosti nacionalnog prava sa evropskim, nego postojeća administrativna i institucionalna spremnost i sposobnost da se efektivno primjenjuje acquis. ${ }^{55}$

\section{ZAKLJUČAK}

Nakon početnih koraka razvoja prava zaštite potrošača u Bosni i Hercegovini i nastojanja da se donese novi zakon o obligacionim odnosima u koji bi se implementirale odredbe direktiva potrošačkog acquis-a EU, koje se odnose na potrošačke ugovore i zabranjene ugovorne klauzule, prešlo se na kodifikovanje heterogenog sadržaja građanskopravnih i javnopravnih normi u Zakon o zaštiti potrošača. Prema sadašnjem stanju, pored kodifikovanog sadržaja u ZZP BiH i ZZP RS, razvio se paralelni sistem posebnih propisa kojima se implementiraju pojedine direktive potrošačkog acquis-a EU.

$51 \quad$ Ibid.

52 Član 17. ZOO.

53 Povlakić, M., 2019, str. 13.

54 Ibid., str. 14.

55 Ibid., str. 15. 
Preovlađuju ocjene o tromosti domaćeg zakonodavstva u tempu preuzimanja direktiva, postojanju velike vremenske distance od donošenja do preuzimanja direktiva i nespremnosti domaćih organa da korektno izvedu proces implementacije direktiva/smjernica. Pored toga, zapaža se hronična nedovoljna informisanost i edukovanost kako potrošača i njihovih udruženja tako i upravnih organa, ombudsmana i pravosudnih tijela. Osjeća se nedostatak propisane metodologije primjene postojećeg domaćeg zakonodavstva i direktne primjene direktiva tumačenjem domaćih propisa koji su preuzeli direktive u smislu odredaba direktiva. Nesumnjivo se obistinilo predviđanje kako domaće zakonodavstvo neće moći uspješno pratiti dinamiku donošenja i izmjena i dopuna direktiva EU metodom harmonizacije, implementacije i kodifikacije, te sada preovlađuje metoda parcijalnog preuzimanja direktiva u posebne zakone. U Bosni i Hercegovini dodatno opterećenje predstavlja nepostojanje unutrašnje harmonizacije, jer je pravni sistem multiplikovan na više podsistema koji samostalno i nepovezano egzistiraju.

U pogledu procesnopravne materije zaštite potrošača, posebne odredbe ZZP RS ne korespondiraju sa materijalnopravnim ovlašćenjima po kojima se potrošači ne mogu odreći svojih prava, niti njima slobodno raspolagati. To upućuje da su u materijalnopravnim odredbama prava zaštite potrošača suspendovana osnovna načela obligacionog prava, načelo autonomije volje i načelo dispozitivnosti normi, a ta načela nalaze svoj odraz u načelima građanskog procesnog prava. Stoga su posebne odredbe ZPP RS nedosljedne, jer ne izriču zabranu raspolaganja potrošačkim pravima, a samim tim ne korespondiraju sa osnovnim principima građanskopravne zaštite. Stoga je po svojoj pravnoj prirodi zaštita potrošača nametnuta i predstavlja vanjski faktor koji je potrošačima imperativnim normama zagarantovan.

Borba za uređivanje fer i poštenih tržišnih odnosa dugo se odvijala samo vodeći računa o poslovnim subjektima, da se, između njih, suzbije nelojalna konkurencija i monopolističko djelovanje. Ta borba nije ni danas završena, ali se otvorio i front $\mathrm{u}$ koji se nacionalne države uključuju posredstvom nadnacionalne superdržave kao što je Evropska unija. U ovu titansku borbu sada se uključuju i potrošači kojima se daju prava koja oni sami i posredstvom svojih slabašnih i neafirmisanih organizacija i udruženja, barem na našem prostoru, teško da mogu samostalno zaštititi. Potrošačima se pruža donkihotska prilika da se umjesto države i sličnih javnih faktora izbore za svoja proklamovana prava, protiv jačih tržišnih učesnika protiv kojih se ni državne vlasti ne upuštaju u otvoren obračun. Noam Čomski, najuticajniji svjetski intelektualac, ${ }^{56} \mathrm{u}$ intervjuu filozofu Srećku Horvatu, koji je objavljen na stranici pokreta DIE M 25, istakao je, između ostalog, da problemi sa nesavlađivanjem epidemije covid 19 potiču od „neoliberalne kuge koja je zamijenila državu. "Javni sektor je oslabio na račun korporativnog, koji ne vodi računa o javnim interesima, nego o privatnom profitu. Čomski poručuje da je neoliberalnu ideologiju promovisao Ronald Regan, koji je izbacio krilaticu: „Vlada je problem, oslobodimo se vlade“, što, po Čomskom znači, prepustimo se odlukama privatnih tiranija koje nemaju odgovornosti prema javnosti. 
S druge strane Atlantika, Margaret Tačer je poručivala kako „ne postoji društvo, samo pojedinci“. Tako nešto se može vidjeti i na evropskom modelu zaštite potrošača kao nastojanje da se „društvo“ oslobodi brige za pojedince-potrošače i da ih, pred nemilosrdnom korporacijskom neodgovornošću, prepusti sebi samima, da se sami brane. Velike svjetske krize, kao što je ekološka kriza, klimatske promjene ili prirodne katastrofe i pandemije, tjeraju svjetske moćnike da reaguju i uvode strože zaštitne mjere i norme. To je vezano i za podizanje svijesti potrošača i nastojanja da im se destimuliše vještački izgrađeni potrošački mentalitet i da ih reorganizuju tako da manje troše, smanje putovanja i kućni otpad i počnu da „kupuju domaće“. Tako bi se postiglo da se prestanu besomučno trošiti prirodna bogatstva - voda, šume, zemlja, rude i sl. - s ciljem da se proizvedu najraznovrsnija dobra, njima zasitila potrošačka groznica i proizvelo neizmjerno mnogo otpada.

\section{LITERATURA}

1. Bajraktarević, D., 2011, Zaštita potrošača na tržištu finansijskih usluga u Bosni i Hercegovini, Pravna misao, 1-2.

2. Bikić, E., Petrović, A., 2011, Koncept potrošačkog ugovora u pravu BiH, Pravna misao, 3-4.

3. Mayer, T., 2002, Reforma obligacionog prava u Nemačkoj, Pravni život, 10.

4. Morait, B. et al., 2002, Reforma Zakona o obligacionim odnosima u Bosni i Hercegovini (RS iFBiH), Srpska pravna misao, 1-4.

5. Perović, S., 2002, Stručno mišljenje o Nacrtu Zakona o obligacionim odnosima FBiH/RS sa stanjem 28. 1. 2003, Srpska pravna misao, 1-4.

6. Povlakić, M., 2019, Evropa ante portas - da li su vrata zaključana? (Povodom sudske presude o ugovorima sklopljenim van poslovnih prostorija), Domaća i strana sudska praksa, januar-februar-mart 2019. godine.

7. Sabljica, S., 2015, Politika zaštite potrošača u Bosni i Hercegovini u procesu evropskih integracija, Pravna misao, 3-4.

8. Simović, Š., 2019, Zaštita prava potrošača u alternativnim mehanizmima za rješavanje potrošačkih sporova, Pravna misao, 5-6.

\section{PROPISI}

1. Direktiva 85/577 EWG Vijeća od 20. decembra 1985, koja uređuje zaštitu potrošača u slučaju ugovora zaključenih van poslovnih prostorija.

2. Direktiva 90/314/EWG Vijeća od 13. juna 1990. o paušalnim putovanjima.

3. Direktiva 93/13 EWG Evropskog parlamenta i Vijeća od 5. aprila 1993. o zabranjenim klauzulama u potrošačkim ugovorima.

4. Direktiva 97/7 EZ Evropskog parlamenta i Vijeća od 20. maja 1997. o prodaji na daljinu.

5. Direktiva Evropskog parlamenta i Vijeća od 19. maja 1998. o tužbama na propuštanje radi zaštite interesa potrošača. 
6. Objašnjenja uz predlog Nacrta Zakona o obligacionim odnosima, JU Centar za edukaciju sudija i tužilaca u FBiH/JU Centar za edukaciju sudija i tužilaca u RS u kooperaciji sa GTZ, (Sarajevo/Banja Luka), juli, 2006.

7. Zakon o Agenciji za bankarstvo RS, Sl. glasnik RS, br. 10/98, 10/00, 18/01, 71/02, 18/03 39/03.

8. Zakon o Agenciji za bankarstvo FBiH, Sl. novine FBiH, br. 9/96, 27/98, 20/00, 45/00.

9. Zakon o Agenciji za osiguranje BiH, Sl. glasnik BiH, br. 12/04.

10. Zakon o bankama, Sl. novine FBiH, br. 39/98, 32/01.

11. Zakon o bankama, Sl. glasnik RS, br. $4 / 17$.

12. Zakon o bankama, Sl. glasnik RS, br. 44/03.

13. Zakon o bankama RS, Sl. glasnik RS, br. 3/16.

14. Zakon o društvima za osiguranje, Sl. glasnik RS, br. 17/05, 01/06, 64/06.

15. Zakon o društvima za osiguranje u privatnom osiguranju, Sl. novine FBiH, br. 22/05.

16. Zakon o hrani, Sl. glasnik BiH, br. 40/04, Sl. glasnik RS, br. 19/17.

17. Zakon o Komisiji za vrijednosne papire, Sl. novine FBiH, br. 39/98, 16/00, 18/01, 71/02, 18/03, 39/03.

18. Zakon o mikrokreditnim organizacijama RS, Sl. glasnik RS, br. 116/11.

19. Zakon o nedopuštenom oglašavanju, Sl. glasnik RS, br. 52/12, Sl. novine FbiH, br. $101 / 16$.

20. Zakon o obligacionim odnosima u Republici Srpskoj, Sl. glasnik SFRJ, br. 29/78, 39/85, 45/89, 57/89, Sl. glasnik RS, br. 17/93 i 3/96.

21. Zakon o obligacionim odnosima u FBiH, Sl. glasnik SFRJ, br. 29/78, 39/85, 45/89, 57/89, Sl. list RBiH, br. 2/92, 13/93, 13/94, Sl. novine FBiH, br. 29/03.

22. Zakon o općoj sigurnosti proizvoda, Sl. glasnik BiH, br. 10/09.

23. Zakon o opštoj sigurnosti proizvoda, Sl. glasnik RS, br. 46/17.

24. Zakon o osiguranju depozita u bankama BiH, Sl. glasnik BiH, br. 20/02, 18/05, 100/08 i $75 / 09$.

25. Zakon o osiguranju od odgovornosti za motorna vozila i ostalim obaveznim osiguranjima od odgovornosti, Sl. glasnik RS, br. 17/05, 64/06.

26. Zakon o obveznim odnosima, Narodne novine, br. 35/05 i 41/08.

27. Zakon o parničnom postupku Republike Srpske, Sl. glasnik Republike Srpske, br. 58/03, 85/03, 74/05, 63/07, 105/08 - odluka US, 45/09 - odluka US i 61/13.

28. Zakon o posredovanju u osiguranju, Sl. glasnik RS, br. 17/05, 64/06.

29. Zakon o posredovanju u privatnom osiguranju, Sl. novine FBiH, br. 22/05.

30. Zakon o tržištu hartija od vrijednosti, Sl. glasnik RS, br. 92/06.

31. Zakon o tržištu vrijednosnih papira, Sl. novine FBiH, br. 85/08.

32. Zakon o zaštiti korisnika financijskih usluga, Sl. novine FBiH, br. 31/14.

33. Zakon o zaštiti korisnika finansijskih usluga, Sl. novine FBiH, br. 31/14.

34. Zakon o zaštiti potrošača Republike Hrvatske, Narodne novine, br. 41/14, 110/15, $14 / 19$.

35. Zakon o zaštiti potrošača Republike Srpske, Sl. glasnik RS, br. 6/12, 63/14, 18/17.

36. Zakon o zaštiti potrošača u BiH, Sl. glasnik BiH, br. 25/06 i 88/15.

37. Zakon o zaštiti potrošača u Bosni i Hercegovini, Sl. glasnik BiH, br. 17/02, 44/04.

38. Zakon o zaštiti potrošača u Bosni i Hercegovini, Sl. glasnik BiH, br. 25/06. 
39. Zakon o zaštiti žiranata, Sl. novine FBiH, br. 103/13.

40. Zakon o zaštiti žiranata FBiH, Sl. novine FBiH, br. 100/13.

\title{
THE SUBSTANTIVE AND PROCEDURAL LEGAL COMPONENTS OF DEFINING CONSUMER RIGHTS IN BOSNIA AND HERZEGOVINA
}

\author{
Branko Morait \\ SUMMARY
}

The article presents the state and perspectives of consumer protection development in Bosnia and Herzegovina. Despite the initial fragmentary transposition of certain EU consumer directives, this process has slowed down. A codified law on consumer protection was adopted and judicial protection was enabled through a collective action. The process of transposition and implementation of EU directives in $\mathrm{BiH}$ is expected to be continued.

Key words: consumer, trader, codification, protection, directives. 